\title{
Impacting Pre-service Teachers' Attitudes toward Inclusion
}

\author{
Roben W. Taylor ${ }^{1} \&$ Ravic P. Ringlaben ${ }^{2}$ \\ ${ }^{1}$ Assistant Professor, Curriculum and Instruction, Jacksonville State University, Jacksonville, Alabama, USA \\ ${ }^{2}$ Associate Professor, Special Education Programs, Collaborative Support and Intervention, University of West \\ Georgia, Carrollton, Georgia, USA \\ Correspondence: Roben W. Taylor, Assistant Professor, Curriculum and Instruction, Jacksonville State \\ University, 700 Pelham Rd N, Jacksonville, AL. 36265, USA. E-mail: rwtaylor@jsu.edu
}

Received: May 17, 2012 Accepted: May 28, 2012 Online Published: July 19, 2012

doi:10.5539/hes.v2n3p16 URL: http://dx.doi.org/10.5539/hes.v2n3p16

\begin{abstract}
Despite federal mandates to educate students with disabilities in the least restrictive environment, teachers continue to have mixed feelings about their own preparedness to educate students with disabilities in the general education setting. However, research has documented that teachers with more positive attitudes toward inclusion are more likely to adjust their instruction and curriculum to meet individual needs of students and have a more positive approach to inclusion. With inclusion becoming the norm in today's schools, teacher educators are now faced with the challenge of making significant changes to educational programs in preparing pre-service teachers to be ready to meet the needs of all students. These programmatic changes mirror the continuous melding transformations in progress now in traditional general education and special education programs. However, there is limited information about how these new teacher educator programs influence pre-service teachers' confidence or attitudes toward inclusive education as future teachers. To investigate this influence of teacher preparation programs on pre-service teachers' attitudes toward inclusion, a survey method was used to collect data from pre-service teachers in one teacher-preparation program. The responses from pre-service teachers were analyzed indicating that pre-service teachers from this particular teacher preparation program in which general education curricula were infused with special education curricula in special education survey courses had improved positive attitudes and confidence toward inclusion. The implications of this study for practice and future research are discussed.
\end{abstract}

Keywords: attitudes, special education, instruction, inclusion, preparedness

\section{Introduction}

The inclusion of students with disabilities is now a world-wide practice (Leyser \& Romi, 2008; Brownlee \& Carrington, 2000; Hegarty, 1998; and, Sebba \& Ainscow, 1996). "Teachers set the tone of classrooms, and as such, the success of inclusion may well depend upon the prevailing attitudes of teachers as they interact with students with disabilities in their classrooms" (Carroll, Forlin \& Jobling, 2003, p. 65).

With the passage of No Child Left Behind (NCLB) in 2001, public education for students with special needs changed drastically. Questions began to arise regarding the attitudes and self-efficacy of general education teachers with the introduction of such a diverse population of students into their classrooms. As universities prepare pre-service teachers to meet the demands of teaching these students in their future classrooms, teacher preparation professionals need to gauge how well they are preparing candidates to teach all students within the classroom. A significant number of studies from a variety of countries have discerned that pre-service teachers had concerns about working with students with disabilities (Forlin, Loreman, Sharma \& Earle, 2009; Ryan, 2009; Brackenreed \& Barnett, 2006; Forlin, Jobling \& Carroll, 2003; Subban \& Sharma, 2006; Gill \& Clough, 2004; Alghazo, Dodeen \& Algaryouti, 2003; Martin, Ireland, Johnson \& Claxton, 2003; Forlin, Jobling \& Carroll, 2001; Avramidis, Bayliss, \& Burden, 2000). Attitudes of preservice teachers are a critical component to the inclusion of students with disabilities (Forlin, et al, 2009; Brownlee \& Carrington, 2000). "The shaping of positive attitudes toward students with disabilities is an important aspect of the education of pre-service teachers" (Sze, 2009, p. 53). It is the credentialing agencies responsibility to ensure pre-service teachers possess a professional attitude toward inclusion students and are confident in their ability to meet the needs of all students (Brackenreed \& Barnett, 2006; Forlin, et al, 2003. 


\section{Theoretical Framework}

Pace (2003) reports teacher attitudes toward inclusion have been well documented. Today's educators must recognize how their own personal attitudes and actions affect all students' education. Bandura (1982) postulated that even though individuals might recognize that they "know" some specific action should be done to produce a desired behavior; they are still unwilling to attempt this specific action if they do not have the knowledge of how to carry it out completely. According to Scruggs and Mastropieri's (1996) meta-analysis of 28 studies conducted from 1958 to 1995 , teachers overwhelmingly approve the idea of including all students in their classrooms. Imperative to note is that one third of the teachers in these studies revealed they felt ill prepared in requisite skills needed to meet the needs of students with disabilities and also felt they lacked time and resources needed for successful instruction. In other words, teachers like the idea of inclusion, but the realities of today's education dictated otherwise (Van Reusen, Shoho, \& Baker, 2001). Past studies also support this investigation by revealing teacher attitudes and the direct result it has on instructional design. Positive attitudes toward students with disabilities are an important feature in the education of pre-service teachers. Cook, Tankersly, Cook and Landrom (2000) 'propose that teachers' attitudes toward their actual included students, rather than their opinions regarding the abstract concept of inclusion represent a more potent and parsimonious predictor of quality of education for included students with disabilities" (p. 116). Teachers who lack training in appropriate strategies for working with students with disabilities often feel negatively toward students with disabilities, thereby lessening the likelihood of success for students with disabilities.

While there is no doubt that teacher attitudes influence the success of students with disabilities in their classrooms, attention must be given to the importance of pre-service teacher training programs in shaping these attitudes through positive education experiences. To explain, teachers' beliefs are heavily steeped in their own experiences while they were students (Pajares, 1992). This idea along with the combination of teacher education programs work in tandem forming attitudes as training falls in line with prevailing ideas within the context of school (Acker, 1990; D'Andrage, 1981). Accordingly, if pre-service teachers are given the opportunities to work and interact with different categories of students with disabilities and appropriately trained in strategies for working with these students, they are more likely to exhibit greater confidence and positive attitudes toward inclusion (Burke \& Sutherland, 2004; Coates, 1989). Teacher philosophies about students change their behaviors in ways that sanction initial expectations. This is also infamously known as the self-fulfilling prophecy. Teacher perception of students with disabilities creates these students collective reality. Even as far back as 1970, Brophy and Good suggested that teachers respond to students differently based on preconceived expectations and those students with and without disabilities likely respond to this behavior by lowering their self-concept and achievement goals to conform to these teachers' expectations.

As inclusion becomes the norm in today's school, general education pre-service teachers find themselves needing to know how to meet the needs of a myriad of diversity in terms of students with different learning styles and abilities. Many pre-service teachers have little or no experience in working with students with special needs and as a result feel inadequately prepared for their future classrooms. This limited exposure and preparation increases anxiety and fear from the students with disabilities (Everhart, 2009; D'Alonzo, Giordano, \& VanLeeuwen, 1997) and the teachers who teach them.

The literature reviewed for this study indicates that one of the most important predictors for the successful assimilation of students with disabilities in the general education classroom stems from the attitudes of general education teachers. Therefore, pre-service teachers' attitudes toward students with disabilities should be appraised throughout their program and not just in one or two courses to ensure these future teachers are educated in accepting as true that all students deserve the chance to succeed. This study represents a starting point for coming to terms with teaching students with differences. It is the continuation of the move toward a truly inclusive education for all. It is the hope that an introduction to special education course will benefit pre-service teachers in gaining an understanding of students with special needs, thereby increasing their confidence level in teaching all learners.

\section{Purpose}

Jacksonville State University in Jacksonville, Alabama, wanted to ensure pre-service candidates were receiving baseline training for candidates for certification in being able to prepare, provide, and evaluate students who were identified to be special education and were in the inclusion classrooms of the public schools. These candidates are from all program areas of general education and special education. It has been the practice of this institution to require all candidates for certification to successfully complete a survey course in special education This course has as two of its goals: 1) knowledge of the general characteristics of disabilities and of their impact 
on cognitive development and learning and 2) knowledge of cultural, ethnic, gender, linguistic, and socio-economic differences and how these may affect individual learner needs, preferences and styles.

The objectives for the survey course taken by all candidates for certification address issues that assist candidates in developing the confidence needed to teach these students with special needs. Thus the purpose of the study administered to the various program candidates enrolled in the special education survey course in fall 2011 was to answer the following questions: 1) Can attitudes toward inclusion be positively affected through a survey course in special education? 2) Can pre-service teachers' abilities, self-efficacy and confidence levels when working with students with special needs be improved through knowledge gained in a survey course? 3) Can a special education survey course improve knowledge about adapting their teaching for students with disabilities?

During the Fall Semester 2010, all participants of the study were enrolled in Survey of Special Education and were asked to complete a pre-course survey and a post-course survey to assess their attitudes toward inclusion and perceptions of their teaching self-efficacy. The purpose of the study was to determine the effect of a 15 week introductory special education course on pre-service students interested in pursuing education and their attitudes toward inclusion, their personal sense of self-efficacy and their knowledge about adapting their teaching for students with disabilities in their own future classrooms. During the first and last class meeting, students were asked to complete two surveys and a semi-structured interview. These instruments were used with permission given to the researchers to adapt each scale as needed for the purposes of this study. One study used was based on the Opinions Relative to the Integration of Students with Disabilities (ORI) Scale (Antonak \& Larrivee, 1995) which was a revised version of the Opinions Relative to Mainstreaming Scale originally developed by Larrivee and Cook (1979). Sample items included: a) students with disabilities can best be served in general education classrooms; b) students with disabilities are likely to create confusion in the general education classroom; and c) students with disabilities will not monopolize the general education classroom teacher's time. Another instrument utilized for this study was the Teachers' Sense of Efficacy Scale (TSES) (Tschannen-Moran \& Woolfolk Hoy, 2001). This scale consisted of 24 items that respondents rated on a nine-point scales ranging from 'nothing' to 'a great deal'. Sample items included: a) how well can you implement alternative strategies in your classroom; b) how much can you do to control disruptive behavior in the classroom; and c) how much can you do to motivate students who show low interest in schoolwork? Classroom interviews followed in a semi-structured format and lasted approximately 40 minutes each. The interviews were not audio taped, but each student was responsible for taking notes and summarizing their partner's responses in written form to the course instructor for no point value. These interview questions were adapted with permission from a previous study published by Brownlee and Carrington (2000). The pre-course interview included questions such as: a) tell me about your experiences with people with disabilities; and b) what do you expect to learn from this class? The post-course interview included item such as: a) what have you learned from this class; and b) how did the interview process influence you? There were 295 respondents to the pre-course survey and 190 respondents to the post-course survey. These candidates for certification had not been admitted to the College of Education and Professional Studies when these surveys were taken and were fulfilling pre-admission requirements. The responses to the survey were extremely important in evaluating whether or not this course was providing the students with the necessary skills, attitudes, and confidence they needed to teach students with special needs in the regular education classroom. The students were asked to select one of the following responses for each question posed (a typical Likert scale): strongly disagree, disagree, undecided, agree, and strongly agree. An informed consent was obtained from each student before the student could participate in the study.

Candidates who participated in the survey held at least sophomore or junior level status and were taught by several professors of special education at Jacksonville State University. All professors follow a common course syllabus in this survey course which generally lasts 15 weeks. When this survey was completed, the SPE 300 survey course was required before a student could gain admission to the College of Education and Professional Studies program. The data was entered into MiniTab and the results obtained were used to determine the impact the course had on preparing pre-service teachers for working with students with disabilities in today's classrooms.

All of the questions were categorized into five major subgroups for comparison purposes. The subgroups were diversity acceptance, inclusion issues, discipline issues, academic impact, and teacher preparation. Pearson Chi-Square tests and p-value were computed and examined for each question in the five subgroups. The null hypothesis for the Chi Square test for independence is that the categories of answers are independent. For each test, an individual survey question was one category and the type of test (pre or post) is the other category. A small p-value indicates that the response distribution was significantly different for the post-test when compared to the pre-test. A large p-value indicates that there was no significant difference in responses to the questions for 
either test. Those who left the question blank are included in the Total so the sum of the five categories will not always equal the Total. There were 485 valid cases considered in each test. There were 295 pre-test responses and 190 post-test responses. It is assumed this was due to students withdrawing from the course after the pre-test is given or students were absent the day the post-test was administered.

The Chi-Square and p-value results as well as the significance of the results are displayed in tables below.

Table 1. Diversity acceptance

\begin{tabular}{llll}
\hline Question & $\begin{array}{l}\text { Chi-Square } \\
\text { Test }\end{array}$ & p-value & Significance \\
\hline $\begin{array}{l}\text { 1. Many of the things teachers do with general education students in } \\
\text { a classroom are appropriate for students with special needs. }\end{array}$ & & .000 & Different \\
$\begin{array}{l}\text { 6. Inclusion offers mixed group interaction which will foster } \\
\text { understanding and acceptance of differences. }\end{array}$ & 6.587 & .253 & Different \\
$\begin{array}{l}\text { 15. The contact general education students have with included } \\
\text { students may be harmful. }\end{array}$ & .368 & .985 & No difference \\
$\begin{array}{l}\text { 18. Including the student with special needs will promote his/her } \\
\text { social independence. }\end{array}$ & 4.497 & .480 & $\begin{array}{l}\text { Slightly } \\
\text { Different }\end{array}$ \\
$\begin{array}{l}\text { 21. The integration of students with special needs can be beneficial } \\
\text { for regular students. }\end{array}$ & 6.378 & .173 & $\begin{array}{l}\text { Different } \\
\begin{array}{l}\text { 25. The student with special needs will be socially isolated by } \\
\text { regular classroom students. }\end{array}\end{array}$ \\
$\begin{array}{l}\text { 30. The presence of students with special needs will promote } \\
\text { acceptance of differences on the part of regular students. }\end{array}$ & 4.537 & .064 & Different \\
\hline
\end{tabular}

Generally, there was a significant difference in the pre-course responses to the post-course responses. Although pre-admission candidates for certification showed they believed the same before and after the course regarding the promotion of social independence when students with special needs are taught in inclusive classrooms. The actual results indicate out of 295 respondents 15 either disagreed or strongly disagreed, 235 either agreed or strongly agreed, and 41 were undecided on the pre-course survey for question 18 . Out of 190 post-course respondents on question 18, there were 6 who either disagreed or strongly disagreed, 149 who either agreed or strongly agreed, and 34 who were undecided. Candidates also believed the inclusion of students with special needs in the regular education classroom would promote acceptance of differences by regular education students. For question 30, on the pre-course survey (295 respondents) 12 strongly disagreed or disagreed, 234 agreed or strongly agreed, and 48 were undecided. On the post-course survey (190 respondents) 6 strongly disagreed or disagreed, 143 agreed or strongly agreed, and 39 were undecided. These two results may be due to the fact that many of the respondents could have been in inclusion classrooms during their own high school classes.

Table 2. Inclusion issues

\begin{tabular}{|c|c|c|c|}
\hline Question & $\begin{array}{l}\text { Chi-Square } \\
\text { Test }\end{array}$ & p-value & Significance \\
\hline $\begin{array}{l}\text { 2. The needs of students with special needs can best be served } \\
\text { through special, separate classes. }\end{array}$ & 15.136 & .010 & Different \\
\hline $\begin{array}{l}\text { 5. The extra attention students with special needs require will } \\
\text { be to the detriment of the other students. }\end{array}$ & 17. 844 & .003 & Different \\
\hline $\begin{array}{l}\text { 10. Isolation in a special class has a negative effect on the social } \\
\text { and emotional development of a student with special needs. }\end{array}$ & 7. 299 & .199 & Different \\
\hline $\begin{array}{l}\text { 17. Students with special needs will monopolize the teacher's } \\
\text { time. }\end{array}$ & 5.582 & .233 & Different \\
\hline $\begin{array}{l}20 \text {. Diagnostic-prescriptive teaching is better done by } \\
\text { resource-room or special teachers than by regular classroom } \\
\text { teachers. }\end{array}$ & 4. 134 & .530 & No difference \\
\hline $\begin{array}{l}\text { 23. Inclusion is likely to have a negative effect on the emotional } \\
\text { development of the child with special needs. }\end{array}$ & 9.152 & .103 & Different \\
\hline $\begin{array}{l}\text { 28. Integration of students with special needs should be given } \\
\text { every opportunity to function in the regular classroom setting, } \\
\text { where possible. }\end{array}$ & 5. 252 & .262 & Different \\
\hline
\end{tabular}


These results indicate the candidates responded very differently on the post-course survey than on the pre-course survey. However, question \#20 showed no difference in the results of the two surveys. Students obviously still believe teachers who specialize in teaching students with special needs are the best ones to teach those students in an environment where the students are taught on an individual basis vs. large class instruction.

Table 3. Discipline Issues

\begin{tabular}{|c|c|c|c|}
\hline Question & $\begin{array}{l}\text { Chi-Square } \\
\text { Test }\end{array}$ & p-value & Significance \\
\hline $\begin{array}{l}\text { 3. The classroom behavior of a child with special needs generally } \\
\text { requires more patience from the teacher than does the behavior of a } \\
\text { normal child. }\end{array}$ & 2.547 & .769 & $\begin{array}{l}\text { No } \\
\text { difference }\end{array}$ \\
\hline $\begin{array}{l}\text { 7. It is difficult to maintain order in a general education classroom that } \\
\text { contains students with special needs. }\end{array}$ & 7.889 & .162 & Different \\
\hline $\begin{array}{l}\text { 9. The behavior of students with special needs will set a bad example } \\
\text { for the other students. }\end{array}$ & 6.915 & .227 & Different \\
\hline $\begin{array}{l}\text { 14. Most students with special needs are well behaved in the } \\
\text { classroom. }\end{array}$ & 5.304 & .380 & Different \\
\hline $\begin{array}{l}\text { 19. It is likely that a student with special needs will exhibit behavior } \\
\text { problems in a regular classroom setting. }\end{array}$ & 6.590 & .253 & Different \\
\hline $\begin{array}{l}\text { 29. Students with special needs are likely to create confusion in the } \\
\text { regular classroom. }\end{array}$ & 9.139 & .104 & Different \\
\hline
\end{tabular}

Discipline issues were viewed significantly different after the survey course was completed than before it began. The only question that was not different related to the patience of the teacher for the various types of learners in the classroom. Because all students can exhibit disruptive behavior, it is possible candidates for certification did not find any difference in the students who were inclusion students and regular education students.

Table 4. Academic Impact

\begin{tabular}{llll}
\hline Question & $\begin{array}{l}\text { Chi-Square } \\
\text { Test }\end{array}$ & p-value & Significance \\
\hline $\begin{array}{l}\text { 4. The challenge of being in a general education classroom will } \\
\text { promote the academic growth of the child with special needs. }\end{array}$ & & .314 & Different \\
$\begin{array}{l}\text { 11. The child with special needs will probably develop } \\
\text { academic skills more rapidly in a special classroom than in a } \\
\text { regular classroom. }\end{array}$ & .096 & Different \\
$\begin{array}{l}\text { 12. Most students with special needs do not make an adequate } \\
\text { attempt to complete their assignments. }\end{array}$ & .940 & .919 & No difference \\
$\begin{array}{l}\text { 24. Increased freedom in the classroom creates too much } \\
\text { confusion. }\end{array}$ & 4.361 & .499 & $\begin{array}{l}\text { Slightly } \\
\text { different }\end{array}$ \\
\hline
\end{tabular}

The academic impact questions were responded to a little differently from the others. While the previous three categories showed a predominance of difference in the results, this series of questions did not. They were split in their results. While the two items showing significantly different results indicated candidates believed inclusion students were better prepared academically, those that showed either no difference or only a slightly different outcome related to work outside the classroom and the structure of the classroom. Completing assignments at home is a battle most teachers address from all types of learners; therefore, it should not be considered different for inclusion students and regular education students. The amount of freedom introduced to students with special needs in the regular classroom did appear to change the opinions of some of the students but not many. 
Table 5. Teacher preparation

\begin{tabular}{llll}
\hline Question & $\begin{array}{l}\text { Chi-Square } \\
\text { Test }\end{array}$ & p-value & Significance \\
\hline $\begin{array}{l}\text { 8. General education teachers possess a great deal of the } \\
\text { expertise necessary to work with students with special needs. }\end{array}$ & 17.058 & .004 & Different \\
$\begin{array}{l}\text { 13. Integration of students with special needs will require } \\
\text { significant changes in general education procedures. }\end{array}$ & 2.520 & .774 & No difference \\
$\begin{array}{l}\text { 16. General education teachers have sufficient training to teach } \\
\text { children with special needs. }\end{array}$ & 7.111 & .130 & Different \\
$\begin{array}{l}\text { 22. Students with special needs need to be told exactly what to } \\
\text { do and how to do it. }\end{array}$ & 6.988 & .222 & Different \\
$\begin{array}{l}\text { 26. Parents of students with special needs present no greater } \\
\text { problem for a classroom teacher than those of a normal student. }\end{array}$ & 4.005 & .549 & No difference \\
$\begin{array}{l}\text { 27. Students with special needs will necessitate extensive } \\
\text { retraining of regular teachers. }\end{array}$ & 7.711 & .173 & Different \\
\hline
\end{tabular}

The questions in this section addressed the training and adjustments required by teachers who have students with special needs in the regular classroom. Four of the six questions results in answers that were significantly different. The two areas where there was no difference indicated in the responses was in the change of procedures in the classroom and parental response to general education practices. The candidates did not believe that teachers should change what they do or that parents of students with special needs created more problems for the teacher than regular education students' parents did.

Overall, each of the questions posed were addressed in the questions on the pre-course and post-course surveys. The responses of the students indicated attitudes toward inclusion can be positively affected. It is also shown that pre-service teachers' abilities, self-efficacy and confidence levels when working with students with special needs can be improved through knowledge gained in a survey course. A special education survey course does indeed improve candidates' knowledge and attitudes about adapting their teaching for students with disabilities. This study supports the findings of other research conducted throughout the world (Forlin, et al, 2009; Leyser \& Romi, 2008; Forlin, et al, 2003; and, Shade \& Stewart, 2001).

Further study could be done by asking these same respondents to complete a post-program survey using the same questions after they have had multiple experiences in the general education classrooms through practicum experiences. It would also be interesting to have results generated by levels of certification such as early childhood, elementary, special education, secondary education and K-12 certification areas such as foreign language, music education, and physical education.

Currently, it is highly recommended that the candidates for certification at Jacksonville State University continue to be required to complete a survey course in special education that will introduce them to the various aspects of special education in the public schools today.

\section{References}

Acker, S. (1990). Teachers' culture in an English primary school: Continuity and change. British Journal of Sociology of Education, 11, 257-273. http://dx.doi.org/10.1080/0142569900110302

Alghazo, E. M., Dodeen, H., \& Algaryouti, I. A. (2003). Attitudes of pre-service teachers towards persons with disabilities: Predictions for the success of inclusion. College Student Journal, 37, 515-522.

Antonak, R., \& Larrivee, B. (1995). Psychometric analysis and revision of the Opinions Relative to Mainstreaming Scale. Exceptional Children, 62, 139-142.

Avramidis, E., Bayliss, B., \& Burden, R. (2000). Student teachers' attitudes towards the inclusion of children with special educational needs in the ordinary school. Teaching and Teacher Education, 16, 277-293. http://dx.doi.org/10.1016/S0742-051X(99)00062-1

Bandura, A. (1982). Self-efficacy mechanism in human agency. American Psychologist, 37, 122-147. http://dx.doi.org/10.1037/0003-066X.37.2.122 
Brackenreed, D., \& Barnett, J. (2006). Teacher stress and inclusion: Perceptions of pre-service teachers. Developmental Disabilities Bulletin, 34, 156-176.

Brophy, J., \& Good, T. (1970). Teachers' communication of differential expectations for children's classroom performance: Some behavioral data. Journal of Educational Psychology, 61, 365-374. http://dx.doi.org/10.1037/h0029908

Brownlee, J., \& Carrington, S. (2000). Opportunities for authentic experience and reflection: A teaching program designed to change attitudes towards disability for pre-service teachers. Support for Learning, 15, 99-105. http://dx.doi.org/10.1111/1467-9604.00157

Burke, K., \& Sutherland, C. (2004). Attitudes toward inclusion: Knowledge vs. experience. Education, 125, 163-172.

Carroll, A., Forlin, C., \& Jobling, A. (2003). The impact of teacher training in special education on the attitudes of Australian preservice general educators towards people with disabilities. Teacher Education Quarterly, 30(3), 65-79.

Coates, R. (1989). The regular education initiative and opinions of regular classroom teachers. Journal of Learning Disabilities, 22, 532-536. http://dx.doi.org/10.1177/002221948902200902

Cook, B. G., Tankersley, M., Cook, L., \& Landrum, T. J. (2000). Teachers' attitudes toward their included students with disabilities. Exceptional Children, 67, 115-135.

D'Alonzo, B. J., Giordano, G., \& VanLeeuwen, D. M. (1997). Perceptions by teachers about the benefits and liabilities of inclusion. Preventing School Failure, 42, 4-11. http://dx.doi.org/10.1080/10459889809603162

D'Andrade, R. G. (1981). The cultural part of cognition. Cognitive Science, 5, 179-195.

Everhart, B. (2009). Anxiety of preservice teachers teaching students with disabilities: A preliminary investigation. Education, 129, 704-713.

Forlin, C., Jobling, A., \& Carroll, A. (2001). Preservice teachers' discomfort levels toward people with disabilities. The Journal of International Special Needs Education, 4, 32-28.

Forlin, C., Loreman, T., Sharma, U., \& Earle, C. (2009). Demographic differences in changing pre-service teachers' attitudes, sentiments and concerns about inclusive education. International Journal of Inclusive Education, 1, 195-209. http://dx.doi.org/10.1080/13603110701365356

Hegarty, S. (1998). International perspectives on special education. European Journal of Special Needs Education, 13, 112-115. http://dx.doi.org/10.1080/0885625980130110

Larrivee, B., \& Cook, L. (1979). Mainstreaming: A study of the variables affecting teacher attitude. The Journal of Special Education, 13, 315-324. http://dx.doi.org/10.1177/002246697901300310

Leyser, Y., \& Romi, S. (2008). Religion and attitudes of college pre-service teachers toward students with disabilities: Implications for higher education. Higher Education, 55, 703-717. http://dx.doi.org/10.1007/s10734-007-9084-2

Martin, B. N., Ireland, H., Johnson, J. A., \& Claxton, K. (2003). Perceptions of teachers on inclusion in four Midwest school districts. Rural Education, 12, 13-20.

Pace, D.A. (2003). Field testing the inclusive rubrics. Academic Exchange Quarterly, 7(2), 21-31.

Richards, G., \& Clough, P. (2004). ITE students' attitudes to inclusion. Research in Education, 72, 77-86.

Ryan, T. (2009). Inclusive attitudes: A pre-service analysis. Journal of Research in Special Education Needs, 9 , 180-187. http://dx.doi.org/10.1111/j.1471-3802.2009.01134.x

Scruggs, T. E., \& Mastropieri, M.A. (1996). Teacher perceptions of mainstreaming-inclusion, 1958-1995: A research synthesis. Exceptional Children, 63, 59-74.

Sebba, J., \& Ainscow, M. (1996). International development in inclusive schooling: Mapping the issues. Cambridge Journal of Education, 26(10), 5-17. http://dx.doi.org/10.1080/0305764960260101

Shade, R. A., \& Stewart, R. (2001). General education and special education pre-service teachers' attitudes toward inclusion. Preventing School Failure, 46, 37-41. http://dx.doi.org/10.1080/10459880109603342

Subban, P., \& Sharma,U. (2006). Teachers' perceptions of inclusive education in Victoria, Australia. International Journal of Special Education, 21, 42-52. 
Sze, S. (2009). A literature review: Pre-service teachers' attitudes toward students with disabilities. Education, $130,53-56$.

Van Reusen, A. K., Shoho, A. R., \& Barker, K. S. (2001). High school teacher attitudes toward inclusion. The High School Journal, 84(2), 7-15. 